\title{
The non-native species to the intercontinental regions of Asia (on an example Trans-Baikal territory)
}

\author{
Timofei Boikov, Aleksey Sutkin, Yuriy Rupyshev \\ Institute of General and Experimental Biology, Siberian Branch of the Russian Academy of Sciences, Ulan-Ude, Russia; \\ t-boikov@mail.ru, al-sutkin@mail.ru, rupyshev@mail.ru
}

Received 8 November 2013; revised 8 December 2013; accepted 15 December 2013

Copyright (C) 2014 Timofei Boikov et al. This is an open access article distributed under the Creative Commons Attribution License, which permits unrestricted use, distribution, and reproduction in any medium, provided the original work is properly cited. In accordance of the Creative Commons Attribution License all Copyrights (c) 2014 are reserved for SCIRP and the owner of the intellectual property Timofei Boikov et al. All Copyright (C) 2014 are guarded by law and by SCIRP as a guardian.

\section{ABSTRACT}

This article is devoted to the study of the composition, diversity and distribution of non-native plant elements to the intercontinental regions of Asia on an example Trans-Baikal territory. The number of non-native plants in the Trans-Baikal areas is determined by the degree of urbanization, favorable climate and the availability of skidding ways proximal to their vicinity.

\section{KEYWORDS}

\section{Non-Native Species; Cluster Analysis; Floristic} Division; Index of Similarity; Floristic Originality

\section{INTRODUCTION}

The ecological consequences of human activity appreciably reflected in the degree of vegetative cover defining a noosphere or phytosphere.

The transformation of the vegetative cover is characterized by the disappearance of climax types and the formation of new types, by the simplification of plant community structure, and by the introduction of non-native species [1]. Currently, 48 European countries contribute to the first comprehensive list of non-native species [2]. The database includes 5789 non-native species, and Europe harbors 3749 introduction species, 1780 of which are non-native.

An analysis of the European list of flora (1964-1980) revealed that the number of non-native species increases by 212 species than the previous data [2].

A large diversity of non-native species is concentrated in highly industrial countries. Most are in Belgium (1969), the UK (1779) and the Czech Republic (1379). The most neophytes have been identified in the UK (857), Germany (450), Belgium (447) and Italy (440). Neophyte natu- ralization is conditioned by favorable temperatures and a large amount of precipitation. In Europe, 50\% of neophytes invaded after 1899, 25\% after 1962 and 10\% after 1989.

Approximately 6.2 new species are naturalized annually. They are irregularly distributed throughout Europe, where half of them arise in the four countries described above.

Thus, the Moscow region houses 25\% of the species with non-native vascular structure [3].

The non-native plants in Siberia, however, have been insufficiently studied.

Most of the studies assessing this area were published in the 1990s and were performed in separate areas of Siberia [4]; several additional publications [5] also focused on separate regions and cities.

Two publications [6,7] are particularly notable because they analyze the adventitious element flora in the Tomsk region and Baikal Siberia. A. I. Pyak [6] identified 143 adventitious species from 36 families and 106 genera, and 8 invasive families-Amaranthaceae, Aceraceae, Commelinaceae, Linaceae, Malvaceae, Portulaceae, Tiliaceae, Ulmaceae-from the Tomsk region.

In Baikal Siberia, a previous study [8] identified 186 invasive species, among which 154 have been entered into a Central Siberia Flora check list [9] and only 33 plants were considered as non-native to the region. Most recently, A. V. Verkhozina revealed 352 adventitious species, which accounts for $13 \%$ of the region's flora [7]. She also demonstrated an increase in the drift time of non-native species, where 1 - 2 species per year drifted in the 20th century and 6 - 7 in the 21st century.

The number of non-native plant species in the Far East region has not been defined, and only a few short papers have assessed several small areas and cities [10].

Therefore, studies that assess the role of adventitious species that have appeared due to drift caused by humans, 
particularly potentially dangerous (invasive) species that appear as a vegetative cover in various territories [11], [12], are merited. Contemporary research of adventitious species encompasses both a cataloging of the properties upon introducing new non-native species and an analysis of the consequences of these processes [13].

\section{MATERIALS AND RESEARCH METHODES}

All research was performed in the Trans-Baikal region. The research materials were initially chosen from a list of Siberian Flora [14] and from other papers [9,15-18]. The floristic structure of the following 10 elementary floristic areas was considered [19]: S-Sayan mountains, BS-Baikalian Sayan (within the limits of Trans-Baikal), BU-Baikalian Upland, SU-Stanovoy Upland, VUVitim Upland, SB-Southern Buryatia, AD-Argun Dahuria, OD-Onon Dahuria, SD-Southern Dahuria, and YaD_-Yablonovaya Dahuria (Figure 1).

We assessed the cluster unweighted pair-group averages and Ward's Euclidean distances to evaluate the nonnative species in these areas [20]. The static floristic division (Figure 2) is based on the indices (or coefficient) of association (alias similarity/dissimilarity) in species contents between elementary areas [21]. But in Trans-
Baikal region the floristic richness of the areas varies considerably. Thence it is more appropriate to adopt for the analysis the indices of association which take into account not the similarity or dissimilarity of species contents relatively the mean arithmetic number of species in two lists or relatively the mean arithmetic number of species in an united list but which account the weighted inequality of species amount in the two lists and include also the negative matches in numerator. Meanwhile, the size of an area influences the number of species but it is not expressed by the indices of association.

The florogenetic division was based on the analysis of genus/species spectra. The richness of different genera in species was presented per mille of total species amount in an area, and the clustering in the dendrogram is related to Euclidean distances. This approach is more informative than an analysis of spectra which are reduced to principal taxa in the consequent employment of rank correlation coefficients [22].

Relief diagrams, showing taxonomic originality of floristic areas, were found useful for the interpretation of a floristic division.

\section{RESULT AND DISCUSSION}

Non-native species introduced to new growth condi-

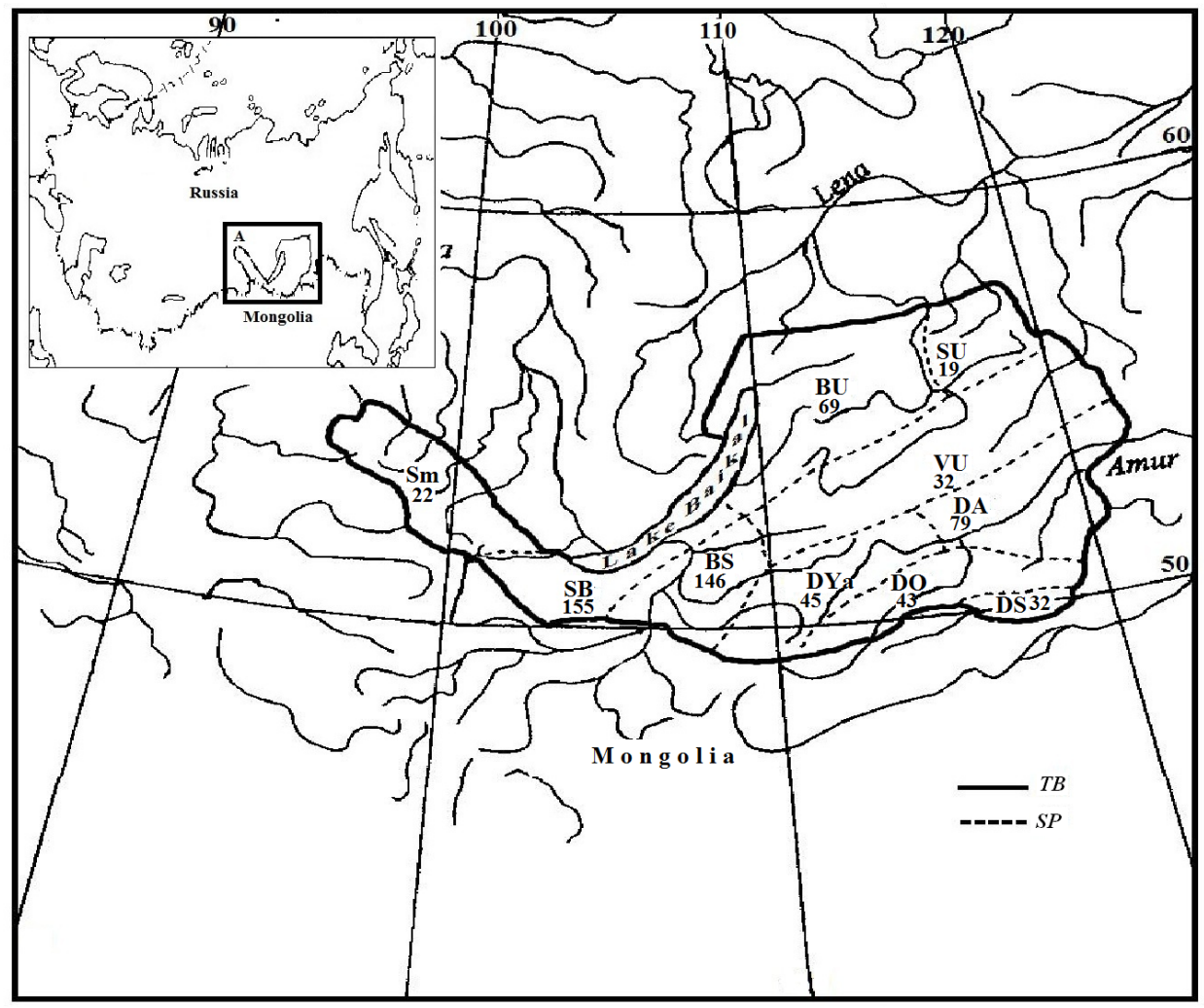

Figure 1. Geographical position (A) and floristic area with number of non-native plant species of the study region, TB-Trans-Baikalian boundary (solid) lines-The bordes between floristic areas (dashed lines). 


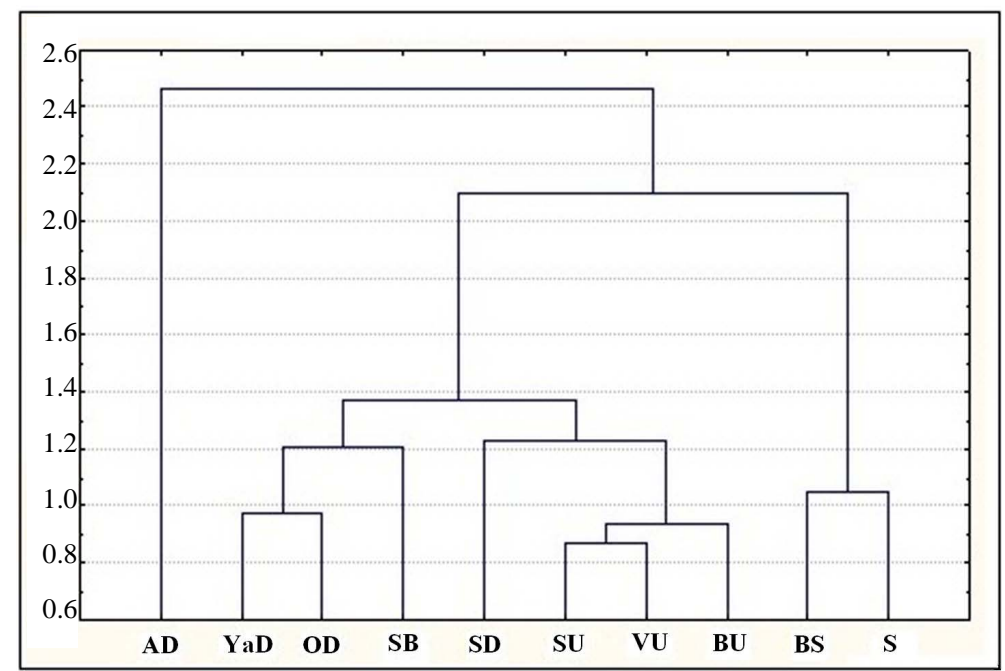

Figure 2. Dendrogram of the floristic agglomersation basing on the index Czekanowski.

tions can impact the natural vegetative communities [23]. Non-native species are classified according to three criteria: the type, time of drift and degree of naturalization, which represents the probability that a species will be observed in the flora at any time. However, we also used the more recent classification for non-native species. Concurrently, we introduced Trans-Baikal tree species, mimicking the number of naturalized species and weeds.

Most published floristic research that focuses on the degree of naturalization categorizes non-native plants into four groups. The approach to cataloging the plant properties upon introducing the new non-native species may possibly be quite sufficient.

It is difficult to establish the time of drift for the first non-native plants (archeophytes) in the Trans-Baikal territory. In Central Europe, people started importing non-native plants in prehistoric times and divided them into distinct archeophytes and neophytes since 1492 [24].

The active colonization of non-native plants in TransBaikal started at an earlier time-during the 11th-12th centuries-when Genghis Khan conquered the western regions of Russia.

When his troops returned home to Trans-Baikal and Mongolia, they likely brought seeds of alien species, such as Artemisia annua L., Carduus nutans L., Sonchus arvensis L., and Setaria viridis (L.) Beauv. This small group of species, which possibly arose from the meadow and gravel plant communities at that time, may have promoted the development of agriculture in the 16th-17th centuries that penetrated into ploughed land and vegetable gardens.

Previously, separate non-native species were cultivated and subsequently, judged to be economically unprofitable plants, occupied weeding plots among cultural plants (Commelina communis L., Helianthus tuberosus
L., and Portulaca oleracea L.).

The active settlement of plants in the Trans-Baikal region from the European part of Russia has begun recently. This expansion correlates with an increasing number of migrants from other regions after 1634, with the construction of large settlements and with the active development of agriculture.

Currently, the inflow of the Western plants has possibly increased enormously, as seen by the presence of Melilotus suaveolens, Trifolium hybridum, T. pratense, T. sativum, Medicago falcata, and M. lupulina. Additionally, the grain crop and grass seed fund may have the following agricultural weeds: Chenopodium album, Avena fatua, Ipomea sibirica, Cuscuta europaea, and Calistegia sepium.

The expansion of non-native species occurred en route to a habitat of aboriginals and migrants and proceeded to the southern humidified Baikal coast and to the narrow flood-plains of the Selenga, Ingoda, Onon rivers and their inflows (Table 1). The weed flora was typically formed by a focus in places that widely cultivated grain crops, including rye, wheat, barley, oat, and millet. The crop seed material may have been delivered from Europe by migrants and was largely comprised of non-native weeds.

Concurrently, in the valleys of southern Pribaikalye and the Selenga, Chikoy, Khilok, Ingoda and Onon rivers and their inflows, ploughed lands and farmlands likely widely harbored Avena fatua L., Bromopsis secalinus L., Dactylis glomerata L., Potentilla norvegica L., Stellaria and media (L.) Villars.

As the construction of the East-Siberian railway was commencing at the end of the 19th century, a movement from Europe to the Pacific Ocean was initiating, where numerous new opportunities for non-native species, in- 
Table 1. Brief description of the nature condition of some sub-regions of Transbaikalia.

\begin{tabular}{|c|c|c|c|c|c|}
\hline & \multicolumn{5}{|c|}{ Sub-regions } \\
\hline & $\mathrm{Sm}$ & SB & $\mathrm{BU}$ & VU & BS \\
\hline The annual precipitation (мм) & 250 & 810 & 376 & 337 & 306 \\
\hline \multicolumn{6}{|l|}{$\begin{array}{l}\text { The sum of positive mean daily air } \\
\text { temperature for the period with the } \\
\text { temperature }\end{array}$} \\
\hline up to $5^{\circ} \mathrm{C}$ & 1142 & 1498 & 1040 & 1364 & 2188 \\
\hline up to $10^{\circ} \mathrm{C}$ & 841 & 1108 & 810 & 1060 & 1860 \\
\hline The frost-free period (average) & 36 & 126 & 58 & 45 & 106 \\
\hline Height above sea level & $1600-2100$ & $456-550$ & $1800-1900$ & $1000-1200$ & $700-750$ \\
\hline Vegetation type & $\begin{array}{l}\text { Alpine vegetation. } \\
\text { Larch forests. }\end{array}$ & $\begin{array}{l}\text { Coniferous forests, } \\
\text { forest-steppe zone. }\end{array}$ & $\begin{array}{l}\text { Alpine vegetation, } \\
\text { larch and pine } \\
\text { forests. }\end{array}$ & $\begin{array}{l}\text { Larch forests, and } \\
\text { meadow } \\
\text { vegetation. }\end{array}$ & $\begin{array}{l}\text { Mountain steppe } \\
\text { and forest-steppe } \\
\text { zone, pine forests. }\end{array}$ \\
\hline
\end{tabular}

cluding Hordeum jubatum L., Amaranthus albus L., A. blitoides S. Wats., A. retroflexus L., Xanthium sibiricum Patrin. ex Widd., and Galinsoga ciliata (Rafin.) Blake, to expand into cities and settlements existed. The drift rates of non-native species constantly increased at that time. In the middle of the last century, they amounted to 1 - 2 plant species per year, to 6 - 7 plant species by the end of the century, and to 13 - 14 species per year at the beginning of the 21st century in Baikal Siberia [7].

Cultural plants represent potential "fugitives from culture" with a different degree of naturalization. Some of the plants observed in the cities and settlements of Pribaikalye, Southern Buryatia and Dauria include Cosmos bipinnatus Cav., Calendula officinalis L., Helianthus annus L., and Saponaria officinalis L. Some examples of naturalized tree and shrub species delivered for landscape gardening include Acer negundo L., A. ginnala Maxim., and Populus balsamifera L. It is possible to predict the occurrence of such "fugitives" in the TransBaikal territory in the future with a high degree of probability. Uncontrolled forest industry fellings and fires in a humid climate contribute to the quick deforestation of the territory, which is observed for the Trans-Baikal region.

Research has demonstrated that the Trans-Baikal territory harbors 242 non-native species $(9.1 \%$ of the region's flora).

Non-native Trans-Baikal plants include 47 families and 156 genera. Exceptionally non-native species represent 8 families, including Amaranthaceae, Cucurbitaceae, Malvaceae, Cannabaceae, Solanaceae, Hydrophyllaceae, Aceraceae, and Commelinaceae, that are characteristic of the adventitious flora fractions of Baikalian Siberia.

The non-native plants are dominated by the following families: Asteraceae-31, Poaceae-29, Brassicaceae24, Fabaceae-21, Caryophyllaceae-12, Rosaceae-
10, Apiaceae and Polygonaceae-8. All of these families are included in the 14 significant Trans-Baikal natural flora families.

The concepts of F. G. Schroeder were employed in the analysis of non-native Trans-Baikal species [23].

The distribution of non-native plants was defined as either occurring by immigration or naturalization according to the following criteria:

1) By immigration: xenophytes, ergasiophygophytes, xeno-ergasiophygophytes (Table 2).

2) By naturalization: epecophytes, colonophytes and ephemerophytes. Nearly half (116 species, 48\%) of the non-native Trans-Baikal species grow in various favorable sites but are not naturalized (Table 3 ).

The flora synanthropization of any territory is a natural phenomenon.

Wild plants typically actively occupy new territories not covered by vegetation, particularly during periods of catastrophic climatic change and during diaspore drifts. When economic activities rapidly change the environmental conditions, the natural vegetation territory is reduced and replaced by another territory consisting of adapted non-native plants that compete with the native species.

The increase in human intervention in the natural habitat of the Trans-Baikal flora may likely increase not only western components but also non-natives influx from the eastern and southern areas.

The method of migration characterizes the transport of 139 plants, whereas 57 (4\%) casually drifted into the Trans-Baikal territory. Sixty-four species (26.4\%) were cultivated in the past or are in culture now and periodically become wild, penetrating arable lands, fields, boundaries, abandoned fields, river flood-plains or natural plant communities. Unintentional drift or naturalization has yielded the appearance of Cannabis sativa L., Centaurea cyanus L., Melilotus officinalis (L.) Pall., and 
Table 2. Distribution of xenophytes on a degree of naturalization and by origin.

\begin{tabular}{|c|c|c|c|c|}
\hline \multirow{2}{*}{ Groups on a degree of naturalization- } & \multicolumn{3}{|c|}{ Groups of non-native plants by origin } & \multirow{2}{*}{ In total } \\
\hline & Western & East & Southern & \\
\hline Epecophytes & 74 & 7 & 5 & 86 \\
\hline Colonophytes & 25 & 2 & 7 & 34 \\
\hline Ephemerophytes & 17 & 1 & 1 & 19 \\
\hline In total & 116 & 10 & 13 & 139 \\
\hline
\end{tabular}

Table 3. Distribution of non-native plants of Transbaikalia on a degree of naturalization and a way of migration.

\begin{tabular}{ccccc}
\hline \multirow{2}{*}{$\begin{array}{c}\text { Groups of species of plants on a } \\
\text { degree of naturalization }\end{array}$} & Xenophytes & Eroups of species till ways of migration & Total \\
\cline { 2 - 4 } Epecophytes & 86 & 29 & Xenoergasiophygophytes & 19 \\
Colonophytes & 34 & 32 & 18 & 24 \\
Ephemerophytes & 19 & 3 & 2 & 24 \\
Total & 139 & 64 & 39 & 242 \\
\hline
\end{tabular}

Note: Areas of plants: CP—circularpolar, EuA—eurasian, E—european, EaA—east-asiatic.

Phacelia tanacetifolia Bentham.

Epecophytes are the most numerous plant types in all of groups, where western species dominate. Most of them appeared in the Trans-Baikal territory a long time ago.

Some of the plants were likely introduced during the period of active (mass) settlement of this territory by peasants from the European part of Russia during the 17th-18th centuries, with subsequent development of agriculture.

Since the 20th century, the appearance of new nonnative plants has been correlated with further development of a railway transport in the Trans-Baikal region, characterized by increased road networks, intensive agricultural development, and the use of new crop cultures.

Therefore, the active drift of non-native plants into the Trans-Baikal territory correlates with anthropogenic changes in the habitat and the conditions that promote a successful competition between non-native and native plants. It is possible to predict an increase in the Trans-Baikal floral diversity based on the drift of non-native plants from the western and south-eastern territories.

The majority of non-native plant species (77\% - 86\%) in all Trans-Baikal areas are derived from Eurasian and circumpolar areas [EuA, CP]. Additionally, the most nonnative species of European and East Asian origin have been identified in the Sayan Mountains [Sm] and the Baikalian Sayans (within the limits of Trans-Baikal [BS], Southern Buryatia [SB]) (Table 4).

The concept of modern areas that harbor casually drifted non-native plants, along with other data that con- tribute to their drift mechanisms (the transport network, a large freight traffic flow, the proximity of large industrial complexes) reveals several putative methods of their introduction into the territory from the West.

Non-native plants are predominantly of a western origin, 139 plants (57\%), and only 10 - 13 non-native plants drifted from southern or eastern territories. This is because the settling of the Russian suburbs, including Siberia and Trans-Baikal, occurred from the western areas of the country. Agricultural development demanded the import of cultural grain seeds and grasses, which brought with them weeds.

The unique Trans-Baikal ecological conditions have allowed the adaptation of the non-native families Chenopodiaceae and Amaranthaceae from dry steppes and deserts.

As we discussed earlier, the drift of separate plant species from the West likely began quite early (12 - 13 centuries ago). A cluster analysis demonstrated that during this long period of time, non-native plants occupied the niches and adapted to conditions of to their ecological status and subsequently became well-adapted to the new growth conditions (Figure 2). Other plant groups, particularly ergasiofigophytes, that were introduced by humans sometimes becomes wild. The adaptation of such species to a certain district possibly correlates to the similarity of their origins, where areas where the plants were tested, studied and selected for zoning may display similar climates. The cluster analysis of the diversity of non-native species in Trans-Baikal floristic areas divides the data into 3 large clusters with distinct linkage levels- 
Table 4. Number of non-native plants of various origin in floristic areas of Transbaikalia.

\begin{tabular}{|c|c|c|c|c|c|c|c|c|c|c|}
\hline \multirow{2}{*}{ Chorological groups } & \multicolumn{10}{|c|}{ Floristic areas } \\
\hline & $\mathrm{Sm}$ & SB & BU & VU & SU & BS & $\mathrm{AD}$ & OD & SD & $\mathrm{YaD}$ \\
\hline $\mathrm{CP}$ & 2 & 54 & 29 & 15 & 9 & 42 & 32 & 16 & 13 & 21 \\
\hline EA & 6 & 46 & 22 & 10 & 6 & 44 & 33 & 14 & 11 & 15 \\
\hline $\mathrm{E}$ & - & 28 & 2 & 1 & - & 22 & 3 & 3 & 1 & 1 \\
\hline EA & 11 & 8 & 2 & 2 & 1 & 13 & 3 & 1 & 2 & 2 \\
\hline Total (\%) & 86 & 83 & 77 & 81 & 79 & 74 & 86 & 77 & 78 & 82 \\
\hline Other groups & 3 & 19 & 14 & 4 & 2 & 25 & 8 & 9 & 5 & 6 \\
\hline
\end{tabular}

Note: Areas of plants: CP—circularpolar, EuA—euro-asiatic, E—European, EaA—eastern-asiatic.

Table 5. Structure of flora of Transbaikalia in various floristic areas and number of non-native plants.

\begin{tabular}{ccccccccccc}
\hline Floristic areas & Sm & SB & BU & VU & SU & BS & AD & OD & SD & YaD \\
\hline Number of species in flora & 1056 & 1524 & 1583 & 914 & 839 & 1169 & 832 & 859 & 447 & 971 \\
Number of non-native species & 22 & 155 & 69 & 32 & 19 & 146 & 79 & 43 & 32 & 45 \\
\% non-native species & 2.1 & 10.2 & 4.4 & 3.5 & 2.3 & 12.5 & 9.5 & 5.0 & 7.1 & 4.6 \\
\hline
\end{tabular}

2.5; 1.4; and 1.1. They are called mountain (S, BS), lowmountain (BU, VU) and plain (AD, OD, SB) complexes of non-native species. The distribution of non-native plants in the Trans-Baikal territory occurred because of human migration to the south-eastern Baikal coast and to the basins of the large rivers (Selenga, Ingoda) (Figure 1).

The drift to the mountain areas (S, BU, VU, SU) possibly occurred slower on the valleys of small rivers. The southern Trans-Baikal areas (SB, OD, SD, AD) are welldemarcated (average linkage 1, 2) from the middle mountains (VU, SU, BU) based on the non-native species diversity. The southern area of Argun Dauria (AD) is distinguishable by a diversity of non-native species (79 against 32 - 45). This diversity is caused by an ancient development of the territory that is proximal to China and engaged in active trade.

The Diversity Resistance Hypothesis has long garnered the support of numerous researchers. However, the experimental materials are inconsistent $[25,26]$. The number of non-native species depends on the number of indigenous species, where a larger variety of local flora exhibits a greater effect on the number of non-native plants. Our data indicate that the number of non-native plants does not depend on floristic diversity (Table 5). Conversely, it is determined by the degree of urbanization of the territory via drift or present a short distance away.

Floral and vegetative synanthropization is quite appropriate. It does not correlate with diaspore transfer in all directions in nature. Non-native species drift by anth- ropogenic activity in a direction of a habitat change, which typically encompass conditions that promote the competition between non-native and indigenous species. The level of floral synanthropization in different areas is dependent on the intensity of anthropogenic influences and possibly on the high altitude-zonal differences in plant cover. The floristic steppe complex is exposed to the greatest degree of synanthropization. The floral nonnative fraction is composed of monocarp species not typically derived from western areas but rather from wide areas and settles in disturbed habitats. In the future, the synanthropization in the Trans-Baikal region may grow due to non-native species from eastern and southern territories.

\section{CONCLUSIONS}

1) The non-native fraction of Trans-Baikal flora is represented by 242 species from 47 families and 156 genera. Eight Trans-Baikal flora families exhibit exceptional non-native divergence.

2) Among the invasive Trans-Baikal flora species, 19 (57.4\%) are xenophytes, which were accidentally introduced by humans, and 64 (26.4\%) are ergasiofigophytes.

3) The most invasive species thrive in wide modern areas including Europe and Asia, and are dominated by western species.

4) Three major geographic clusters of non-native species were identified: the mountains, lowlands and plains. The skidding of non-native plants into the southern plains and lowlands likely occurred by a similar mechanism. 


\section{ACKNOWLEDGEMENTS}

The study was supported by the basic project of Department Floristic and Geobotany (VI. 52.1.9. "Modern state vegetation cover diversity and its resources in the Baikal region”).

The authors are greatful to Dr. Bogdan Jackowiak (Adam Mickiewicz University, Poland) for the helpful remarks in the manuscript.

\section{REFERENCES}

[1] Gorchakovskii, P.L. (1979) Tendentsii antropogennykh izmenenij rastitelnogo pokrova zemli. Russian Journal of Botany, 64, 1697-1714.

[2] Lambdon, P.W., Pyšek, P., Basnou, C., et al. (2008) Alien flora of Europe: Species diversity, temporal trends, geographical patterns and research needs. Preslia, 80, 101149.

[3] Ignatov, M.S., Makarov, V.V. and Chichev, A.V. (1990) Konspekt flory adventivnyh rastenij Moskovskoj oblasti. In: Skvorcov, A., Ed., Floristicheskie Issledovanija v Moskovskoj oblasti. Izd-vo “Nauka”, Moscow, 5-105.

[4] Kisileva, A.A. (1988) Nakhodki zanosnykh vidov vo flore tsentralnoj sibiri i krasnoyarskogo kraya. Russian Journal of Botany, 73, 1760-1761.

[5] Sutkin, A.V. (2010) Urbanoflora goroda Ulan-Ude. Buryat Science Center SB RAS Publishers, Ulan-Ude.

[6] Pyak, A.I. (1999) Adventivnye rasteniya tomskoj oblasti. Russian Journal of Botany, 79, 1697-1714.

[7] Verhozina, A.V. (2007) Antropogennaja transformacija flory Bajkal'skoj Sibiri//Sinantropizacija rastenij i zhivotnyh/Mat-ly Vseross. konf. s mezhdunar. uchastiem (Irkutsk, 21-25 maja 2007 g). Izd-vo Instituta geografii SO RAN. S., Irkutsk, 13-15.

[8] Malyshev, L.I. and Peshkova, G.A. (1984). Osobennosti i genezis flory Sibiri: Predbajkal'e i Zabajkal'e. In: Predbaikalia and Trans-Baikal, Eds., Features and Genesis of the Flora of Siberia, Nauka, Novosibirsk, 264 p.

[9] Popov, M.G. (1957-1959) Flora central'noj sibiri. Nauka, Moscow.

[10] Shlotgauer, S.D. (2007) Antropogennaja transformacija rastitel'nogo pokrova tajgi. Nauka, Moscow.

[11] Richardson, D.M., Pyšek, P., Rejmanek, M., et al. (2000) Naturalization and invasion of alien plants: Concepts and definition. Diversity and Distribution, 6, 93-107. http://dx.doi.org/10.1046/j.1472-4642.2000.00083.x

[12] Pyšek, P., Richardson, D.M., Rejmanek, M., et al. (2004) Alien plants in checklists and floras: Towards better communications between taxonomist and ecologist. Taxon, 53, 131-143. http://dx.doi.org/10.2307/4135498

[13] Krylov, A.V. and Reshetnikova, N.M. (2009) Adventivnyj komponent flory Kalugi: naturalizacija vidov. Russian
Journal of Botany, 94, 1126-1244.

[14] Malyshev, L.I. (1987-2003) Flora Sibiriae Izd-vo "Nauka”. Novosibirsk. V.1-14.

[15] Boikov, T.G. (2010) Plant cover of Malchan ridge (Southern Trans-Baikal). Izd-vo "Nauka”, Novosibirsk, 174 p.

[16] Burdukovskaya, G.V. and Anenkhonov, O.A. (2009) Vascular flora of the Ivolga river basin (Western Trans-Baikal) and its changes under human impact. Buryat Science Center SD RAS Publishers, Ulan-Ude.

[17] Anenkhonov, O.A. and Pykhalova, T.D. (2010) The abstract of flora of vascular plants of Trans-Baikal national park. Buryat Science Center SD RAS Publishers, UlanUde.

[18] Pykhalova, T.D., Boikov, T.G. and Anenkhonov, O.A. (2007) Flora of Ulan-Burgasy mountain-ridge (The Eastern Baikal region). Buryat Science Center SD RAS Publishers, Ulan-Ude.

[19] Malyshev, L.I. (2000) Floristic division in the quantitative basis: Baikalian Siberia, Tuva and Outer Mongolia. Flora, 195, 330-338.

[20] Ward, G.H. (1963) Hierarchical grouping to optimise an objective function. Journal of the American Statistical Association, 58, 236-244. http://dx.doi.org/10.1080/01621459.1963.10500845

[21] Rohlf, F.J. (1987) NTSYS-pc: Microcomputer programs for numerical taxonomy and multivariate analysis. The American Statistician, 41, 330. http://dx.doi.org/10.2307/2684761

[22] Malyshev, et al. (1998) The fundamentals of a floristic division. In: Kamelin, R., Ed., Problems of the Botanical Sciences at the Boundary of XX and XXI Centuries: Abstracts, Presented to the II $(X)$ Congress of the Russian Botanical Society, St.-Peterburg, 26-29 May 1998, Vol. 2, Komarov Botanical Institute, St.-Peterburg, 183-184.

[23] Schroeder, F.G. (1969) Klassifizierung der antropochoren. Vegetatio, 16, 225-238.

[24] Mandak, B. and Pyšek, P. (1998) The history of the spread and habitat preferences of Atriplex sagittata (Chenopodiaceae) in the Czech Republic. In: Starfinger, U., Edwards, K., Kowarik, I. and Williamson, M., Eds., Plant Invasions: Ecological Mechanisms and Human Responses, Backhuys Publishers, Leiden, 209-224.

[25] Allen, J.A., Brown, C.S. and Stohlgren, T.J. (2008) Nonnative plant invasions of United States National Parks. Biological Invasions, 11, 2195-2207.

[26] Fridley, J.D., Stachowicz, J.J., Naem, S., Sax, D.F., Seablom, E.W., Smith, M.D., Stohlgren, T.J., Tilman, D. and Von Holle, B. (2007) The invasion paradox: Reconciling pattern and process in species invasions. Ecology, 88, 3-17. http://dx.doi.org/10.1890/0012-9658(2007)88[3:TIPRPA] 2.0.CO;2 